УДК 656.073.235

\title{
УДОСКОНАЛЕННЯ ТЕХНОЛОГІЇ РОБОТИ ПРИКОРДОННОЇ ПЕРЕДАВАЛЬНОЇ СТАНЦІЇ
}

Канд. техн. наук В.В. Петрушов, магістр Н.В. Бочило

\section{СОВЕРШЕНСТВОВАНИЕ ТЕХНОЛОГИИ РАБОТЫ ПРИГРАНИЧНОЙ ПЕРЕДАТОЧНОЙ СТАНЦИИ}

Канд. техн. наук В.В. Петрушов, магистр Н.В. Бочило

IMPROVEMENT WORK TECHNOLOGY OF BORDER TRANSFER STATION

\author{
Cand. of techn. sciences V.V. Petrushov, master N.V. Bochilo
}

У статті розглянуто питання процедури передавання вантажів через кордони Украӥни. Запропоновано методи удосконалення технологій митного контролю та оформлення вантажів, що виконуються на прикордонних передавальних станціях.

Ключові слова: прикордонна передавальна станція, митні операції, простій.

В статье рассмотрен вопрос прочедуры передачи грузов через границы Украины. Предложень методы усовершенствования технологий таможенного контроля и оформления грузов, которые выполняются на приграничных передаточных станциях.

Ключевые слова: приграничная передаточная станция, таможеные операции, простой.

In the article the question of procedure of transferrableness of loads through the borders of Ukraine is considered. The methods of improvement of technologies of custom control and registration of loads that is executed on the frontier transmission stations are offered. One of the main goals of the border transfer station is timely ignoring international trains. The need to ensure the competitiveness of Railways, improve work efficiency, reduce downtime on the edge of the transfer stations.

The article deals with the methods of reducing idle time of cars on transmitting stations passing through customs only one that significantly reduces the downtime of wagons for customs operations. Significant reduction of time of customs and basic operations at border stations, transmission should occur by changing the process by combining some operations that can be performed in parallel.

Keywords: border transfer station, customs operations, detention car.

Вступ. Прикордонна передавальна станція здійснює повний перелік операцій у взаємодії з митною, прикордонною та іншими державними контролюючими службами. Згідно 3 наказом Укрзалізниці від 20.10.1997 p. № 265/Ц [4] станція передачі має бути організована на базі найближчої до кордону сортувальної або дільничної станції. Основні операції, які виконуються на прикордонних передавальних станціях, такі: митний контроль перевізних документів, наявність ліцензій i дозволу на право ввезення та вивезення вантажу, вибіркова перевірка вантажів у поїздах; прикордонний контроль поїздів; фітосанітарний, екологічний, карантинноепідеміологічний контроль; технічний контроль справності вагонів; перевірка кількості та номерів перевізних засобів, що передаються; огляд комерційного стану вагонів (цілісність пломб, запірно-пломбувальних пристроїв (ЗПП), правильність навантаження та кріплення вантажу тощо); засвідчення конторою передач факту передачі поїздів, вагонів та контейнерів; здійснення транспортно-експедиційною конторою контролю за пропуском транзитних вантажів; облік станційним технологічним центром (СТЦ) переходу поїздів, вагонів та контейнерів.

Аналіз останніх досліджень i публікацій. Питанням удосконалення технології роботи прикордонних станцій присвячено чимало досліджень сучасних науковців. У роботі [5] розглянуто питання підвищення ефективності роботи 
прикордонних станцій за рахунок упровадження нових методів управління технологічними процесами на базі інформаційно-керуючих технологій. У [6] йдеться про впровадження комплексних заходів 3 удосконалення технології управління вагонопотоками на прикордонних станціях, зокрема при виконанні додаткової маневрової роботи із затриманими вагонами. Робота [7] пропонує методику кореляційного i регресійного аналізу для визначення ступеня взаємозв'язку між основними факторами ризику i числом затриманих вагонів на прикордонних передавальних станціях в умовах упровадження системи управління ризиками (СУР).

Аналіз технології передавання даних для кожного 3 варіантів пропуску вантажопотоків та доцільність використання системи SUW2000 для вантажних перевезень [8]. Стаття [9] розглядає пріоритетні напрямки досліджень роботи залізничних пунктів пропуску з метою скорочення терміну доставки експортноімпортних вантажів.

Отже, тема удосконалення прикордонних передавальних станцій є актуальною.

Постановка проблеми. Ефективність організації міжнародних перевезень вантажів значно залежить від злагодженої організації роботи прикордонної передавальної станції. При виконанні операцій, які виконуються на прикордонних передавальних станціях, можливі затримки вагонів 3 таких причин:

- збільшення тривалості митних та прикордонних операцій;

- неякісне оформлення перевізних документів;

- технічні та комерційні несправності вагонів;

- відчеплення вагонів, затриманих прикордонними, митними, санітарнокарантинними, ветеринарними та іншими органами;

- тимчасове закриття кордону;

- непрофесійність роботи прикордонних та митних служб.

Для якісної роботи та швидкої переробки вагонів виникає необхідність в удосконаленні технологій роботи прикордонних передавальних станцій.

Мета і задачі дослідження. Метою роботи $\epsilon$ розгляд технології роботи прикордонних передавальних залізничних станцій та покращення їх роботи за рахунок удосконалення процесу обробки вантажопотоків.

Виклад основного матеріалу. Залізниці України у 2014 році перевезли 389,7 млн т вантажів, що менше ніж у 2013 році на 12,2 \%. У внутрішньому сполученні перевезено 182,6 млн т, імпортні перевезення становлять 36,2 млн т, експортні - 141,3 млн т, транзитні 29,5 млн т. При цьому внутрішні перевезення зменшилися на 20,3\%, експорт - на 2,9\%, транзит - на 13,3\%. Імпортні перевезення зросли на 3,7\%. Імпортних вантажів ввезено в Україну залізничним транспортом понад 36 млн т (у 2013 році - близько 35 млн т) збільшення на 3,7 \%. В імпортному сполученні зросли обсяги перевезень кам'яного вугілля (на $6,7 \%$ ); нафти і нафтопродуктів (майже на $20 \%$ ); хімічних і мінеральних добрив (на 80,5\%), зерна і зернових (на 33,1 \%), коксу (в 2,2 рази), солі (на 14,3 \%). Вивезено на експорт упродовж 2014 року 141,3 млн т, що на 2,9 \% менше ніж у 2013 році, коли залізниці перевезли 145,5 млн т. Зменшення відбулося в основному за рахунок кам'яного вугілля (на 23,2\%), нафти і нафтопродуктів (на 3,3\%), чорних металів (на $9,4 \%$ ), хімічних і мінеральних добрив (на $37,5 \%$ ). При цьому збільшилися обсяги перевезень руди залізної і марганцевої (на 8,8 \%), зерна і продуктів помелу (на 11,7 \%) та лісних вантажів (на 9,5 \%). Обсяги перевезень транзитних вантажів у минулому році склали 29,5 млн т, що на 13,3\% менше ніж у 2013 році, коли було перевезено 34,0 млн т. Обсяги транзиту впали за рахунок нафти i нафтопродуктів (на 22,5 \%), вугілля (на 5,5 \%), хімічних і мінеральних добрив (на 30,5\%) та хімікатів (на 28,9 \%) [3].

Зважаючи на зменшення загальних показників роботи залізничного транспорту, виникає необхідність :

- підвищення конкурентоспроможності та потенціалу залізничного транспорту на ринку транспортних послуг;

- залучення додаткових вантажопотоків на територію України;

- розширення географіï міжнародних проектів за участю залізниць України;

- удосконалення тарифної політики Укрзалізниці;

- технічне переоснащення;

- удосконалення перевізного процесу за рахунок сучасних технологій; 
- сучасне облаштування прикордонних переходів [2].

Для злагодженої роботи прикордонних станцій особливо важливе значення у першу чергу має узгодженість взаємодії прикордонної, митної та залізничної служб, а також чітке дотримання домовленостей iз сусідніми країнами про приймання поїздів. Тільки комплексне вирішення пов'язаних з цим питань дає змогу збільшити пропуск вагонів і вантажів через прикордонні переходи.

Багато часу витрачається на оформлення перевізних документів. Для того, щоб скоротити час оформлення та при перетинанні кордону не переоформлювати документи, була створена залізнична накладна ЦІМ/СМГС, як основний перевізний документ. Ця накладна не потребує переоформлення при перетинанні кордону і $\epsilon$ електронною копією транзитної декларації, що значно спрощує процедуруy митного оформлення вантажу.

Скорочення часу передачі вагонів можна досягти проведенням митного огляду лише один раз на території країни, що здає вантаж, за участю працівників обох суміжних залізниць. Для цього перевізник має пред'явити акт огляду митного органу відправлення та цілісність пломб, кузовів, контейнерів. Для втілення таких заходів на залізницях сусідніх країн мають існувати однакові вимоги та нормативи щодо технічного стану вагонів i порядку його контролю. 3 цією метою потрібно уніфікувати відповідні технічні вимоги сусідніх країн та їх залізниць.

Підвищити якість та швидкість обслуговування затриманого вагонопотоку на станції можливо за рахунок проведення операцій 3 вагонами на території, оснащеній відповідними спеціальними спорудами та пристроями. На деяких прикордонних станціях доцільно було б спорудити пункти митного контролю, що значно спрощує роботу з вагонопотоком [10].

Для прискорення обміну даними, що пов'язані 3 перевезенням вантажів, доцільне впровадження новітніх інформаційних систем, що забезпечать взаємодію різних електронних систем окремих залізниць.

Висновок. У сучасних міжнародних вантажних перевезеннях залізничний транспорт може відігравати провідну роль. Для цього необхідно підвищити конкурентоспроможність на ринку. Особливе значення має приділятися скороченню часу виконання митних та основних операцій на прикордонних передавальних станціях за рахунок змінення технологічного процесу шляхом поєднання деяких операцій, які можуть виконуватися паралельно. Також потрібно вдосконалити інформаційне забезпечення перевізного процесу на станціях, що призведе до значного спрощення процесу передачі вантажопотоків на залізниці сусідніх держав.

\section{Список використаних джерел}

1. Альошинський, Є.С. Напрямки удосконалення роботи прикордонних передавальних залізничних станцій на кордонах з країнами СНД [Текст] / Є.С. Альошинський, Н.В. Колесникова // Вісник ХПІ. - 2009. - № 15. - С. 29-34.

2. Обухова, А.Л. Аналіз та пропозиції щодо удосконалення технології роботи прикордонних передавальних станцій [Текст] / А.Л. Обухова, В.О. Бакун // Зб. наук. праць Укр. держ. акад. залізнич. трансп. - Харків: УкрДАЗТ, 2014. - Вип. 144. - С. 10-14.

3. У 2014 році залізниці України перевезли 389,7 млн тонн вантажів [Електронний ресурс]: офіційний веб-сайт Укрзалізниці. - Режим доступу: http://uz.gov.ua/press_center/up_to_date_topic/397668.

4. Згідно з наказом Укрзалізниці від 20.10.1997 р. №265/Ц [Електронний ресурс]. - Режим доступу: http://poizd.uz.ua/53-texnologichnij-proces-roboti-peredavalnoyi-stanciyi.html.

5. Бауліна, Г.С. Удосконалення інформаційно-керуючої системи прикордонної передавальної станції на основі застосування інтелектуальних технологій [Текст] / Г.С. Бауліна // Зб. наук. праць ДонІЗТ. - Донецьк, 2011. - Вип. 25. - С. 39-44.

6. Бауліна, Г.С. Дослідження процесу виконання маневрової роботи із затриманими вагонами на прикордонних залізничних станціях [Текст] / Г.С. Бауліна // Зб. наук. праць ДонІЗТ. - Донецьк, 2013. - Вип. 33. - С.20-25.

7. Альошинський, Є.C Аналіз надійності процедури пропуску міжнародного вантажопотоку через прикордонні передавальні станції в умовах впровадження системи управління ризиками (СУР) 
[Текст] / Є.С. Альошинський // Зб. наук. праць Укр. держ. акад. залізнич. трансп. - Харків: УкрДАЗТ, 2014. - Вип. 150. - С.17-24.

8. Нестеренко, Г.І. Удосконалення технології пропуску вантажопотоків через прикордонні передавальні станції [Текст] / Г.І. Нестеренко, А.І. Кузьменко // Вісник Академії митної служби України. Серія “Технічні науки”. - 2011. - № 2 (46). - С.23-29.

9. Нестеренко, Г.І. Прикордонні перевантажувальні станції у логістичних системах транспортування міжнародних вантажопотоків [Текст] / Г.І. Нестеренко // Вісник Дніпропетр. нац. ун-ту залізнич. трансп. ім. акад. В. Лазаряна. - Дніпропетровськ, 2006. - Вип. 11. - С. 122-125.

10.Альошинський, Є.С. Координація роботи сортувальних станцій України при обслуговуванні міжнародних вантажних вагонопотоків [Текст] / Є.С. Альошинський, К.В. Головастікова, Н.С. Лихачова // Зб. наук. праць Укр. держ. акад. залізнич. трансп. - Харків: УкрДАЗТ, 2010. Вип. 112. - С. 12-17.

Рецензент д-р техн. наук, професор Є.С. Альошинський

Петрушов Василь Володимирович, кандидат технічних наук, доцент кафедри управління експлуатаційною роботою, Український державний університет залізничного транспорту. Тел.: (057)730-10-88.

E-mail: vv181@mail.ru.

Бочило Наталія Вікторівна магістр кафедри управління експлуатаційною роботою, Український державний університет залізничного транспорту. E-mail: bochilo-natalia@mail.ru. Тел. +380634081451.

Petrushov Vasyl, candidate of Science, Department of management of operational work, Ukrainian State University of Railway Transport.Tel.: (057)730-10-88. E-mail: vv181@mail.ru.

Bochilo Natalia, master of management of operational work, Ukrainian State University of Railway Transport. E-mail: bochilo-natalia@mail.ru,+380634081451.

Стаття прийнята 05.10.2015 p. 